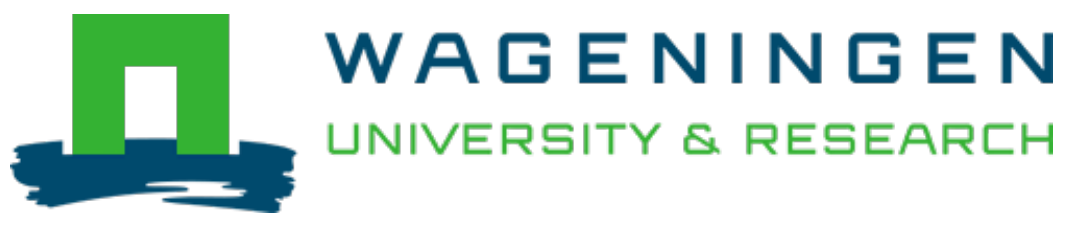

\title{
Trawl fishing impacts on the status of seabed fauna in diverse regions of the globe
}

Fish and Fisheries

Mazor, Tessa; Pitcher, C.R.; Rochester, Wayne; Kaiser, Michel J.; Hiddink, Jan G. et al https://doi.org/10.1111/faf.12506

This article is made publicly available in the institutional repository of Wageningen University and Research, under the terms of article $25 \mathrm{fa}$ of the Dutch Copyright Act, also known as the Amendment Taverne. This has been done with explicit consent by the author.

Article $25 \mathrm{fa}$ states that the author of a short scientific work funded either wholly or partially by Dutch public funds is entitled to make that work publicly available for no consideration following a reasonable period of time after the work was first published, provided that clear reference is made to the source of the first publication of the work.

This publication is distributed under The Association of Universities in the Netherlands (VSNU) 'Article $25 \mathrm{fa}$

implementation' project. In this project research outputs of researchers employed by Dutch Universities that comply with the legal requirements of Article $25 \mathrm{fa}$ of the Dutch Copyright Act are distributed online and free of cost or other barriers in institutional repositories. Research outputs are distributed six months after their first online publication in the original published version and with proper attribution to the source of the original publication.

You are permitted to download and use the publication for personal purposes. All rights remain with the author(s) and / or copyright owner(s) of this work. Any use of the publication or parts of it other than authorised under article $25 \mathrm{fa}$ of the Dutch Copyright act is prohibited. Wageningen University \& Research and the author(s) of this publication shall not be held responsible or liable for any damages resulting from your (re)use of this publication.

For questions regarding the public availability of this article please contact openscience.library@,wur.nl 


\title{
Trawl fishing impacts on the status of seabed fauna in diverse regions of the globe
}

\author{
Tessa Mazor ${ }^{1,2}$ (D) | C. Roland Pitcher ${ }^{1}$ (D) | Wayne Rochester ${ }^{1}$ (D) | Michel J. Kaiser ${ }^{3}$ (D) | \\ Jan G. Hiddink ${ }^{4}$ (D) | Simon Jennings ${ }^{5}$ (D) | Ricardo Amoroso ${ }^{6}$ | Robert A. McConnaughey ${ }^{7}$ (i) | \\ Adriaan D. Rijnsdorp ${ }^{8}$ (D) | Ana M. Parma9 (D) | Petri Suuronen ${ }^{10}$ (D) | Jeremy Collie ${ }^{11}$ | \\ Marija Sciberras $^{12}$ (D) | Lara Atkinson $^{13}$ | Deon Durholtz ${ }^{14}$ | Jim R Ellis ${ }^{15}$ (D) | \\ Stefan G. Bolam ${ }^{15}$ (i) | Michaela Schratzberger ${ }^{15}$ (D) | Elena Couce ${ }^{15}$ (i) | \\ Jacqueline Eggleton $^{15}$ (D) | Clement Garcia ${ }^{15}$ (D) | Paulus Kainge ${ }^{16}$ (D) | Sarah Paulus ${ }^{16}$ | \\ Johannes N. Kathena ${ }^{16}$ | Mayya Gogina ${ }^{17}$ | P. Daniël van Denderen ${ }^{18}$ (D) | \\ Aimee A. Keller ${ }^{19}$ | Beth H. Horness ${ }^{19}$ | Ray Hilborn ${ }^{6}$ (D) \\ ${ }^{1}$ CSIRO Oceans and Atmosphere, Brisbane, Australia \\ ${ }^{2}$ School of Biological Sciences, The University of Queensland, St Lucia, Australia \\ ${ }^{3}$ The Lyell Centre, Heriot-Watt University, Riccarton, Edinburgh, UK \\ ${ }^{4}$ School of Ocean Sciences, Bangor University, Menai Bridge, Wales, UK \\ ${ }^{5}$ International Council for the Exploration of the Sea, H. C. Andersens Boulevard 44-46, Copenhagen, Denmark \\ ${ }^{6}$ School of Aquatic and Fishery Sciences, University of Washington, Seattle, Washington, USA \\ ${ }^{7}$ Alaska Fisheries Science Center, National Marine Fisheries Service, NOAA, Seattle, Washington, USA \\ ${ }^{8}$ Wageningen Marine Research, IJmuiden, The Netherlands \\ ${ }^{9}$ Centro para el Estudio de Sistemas Marinos, CENPAT-CONICET, Puerto Madryn, Argentina \\ ${ }^{10}$ Natural Resources Institute Finland (Luke), Helsinki, Finland \\ ${ }^{11}$ Graduate School of Oceanography, University of Rhode Island, Narragansett, RI, USA \\ ${ }^{12}$ Mediterranean Institute for Advanced Studies (IMEDEA), Illes Balears, Spain \\ ${ }^{13}$ Egagasini Node, South African Environmental Observation Network (SAEON), Cape Town, South Africa \\ ${ }^{14}$ Fisheries Management Branch, Department of Environment, Forestry and Fisheries, Cape Town, South Africa \\ ${ }^{15}$ Centre for the Environment, Fisheries and Aquaculture Science (Cefas), Lowestoft, UK \\ ${ }^{16}$ Ministry of Fisheries and Marine Resources, Swakopmund, Namibia \\ ${ }^{17}$ Leibniz Institute for Baltic Sea Research, Rostock-Warnemünde, Germany \\ ${ }^{18}$ Centre for Ocean Life, National Institute of Aquatic Resources (DTU-Aqua), Technical University of Denmark, Kongens Lyngby, Denmark \\ ${ }^{19}$ The Northwest Fisheries Science Center (NWFSC), NOAA, Seattle, Washington, USA
}

\section{Correspondence}

Tessa Mazor, School of Biological Sciences, The University of Queensland, St Lucia, Qld, Australia.

Email: t.mazor@uq.edu.au

Funding information

Walton Family Foundation; David and Lucile Packard Foundation; Food and Agriculture

Organization of the United Nations

\begin{abstract}
Bottom trawl fishing is a controversial activity. It yields about a quarter of the world's wild seafood, but also has impacts on the marine environment. Recent advances have quantified and improved understanding of large-scale impacts of trawling on the seabed. However, such information needs to be coupled with distributions of benthic invertebrates (benthos) to assess whether these populations are being sustained under current trawling regimes. This study collated data from 13 diverse regions of the globe spanning four continents. Within each region, we combined trawl intensity
\end{abstract}


distributions and predicted abundance distributions of benthos groups with impact and recovery parameters for taxonomic classes in a risk assessment model to estimate benthos status. The exposure of 220 predicted benthos-group distributions to trawling intensity (as swept area ratio) ranged between $0 \%$ and $210 \%$ (mean $=37 \%$ ) of abundance. However, benthos status, an indicator of the depleted abundance under chronic trawling pressure as a proportion of untrawled state, ranged between 0.86 and 1 (mean $=0.99$ ), with $78 \%$ of benthos groups $>0.95$. Mean benthos status was lowest in regions of Europe and Africa, and for taxonomic classes Bivalvia and Gastropoda. Our results demonstrate that while spatial overlap studies can help infer general patterns of potential risk, actual risks cannot be evaluated without using an assessment model that incorporates trawl impact and recovery metrics. These quantitative outputs are essential for sustainability assessments, and together with reference points and thresholds, can help managers ensure use of the marine environment is sustainable under the ecosystem approach to management.

\section{KEYWORDS}

benthic invertebrates, ecosystem-based fisheries management, risk assessment, species distribution modelling, sustainable fisheries, trawling

\section{1 | INTRODUCTION}

Bottom trawling (such as beam, otter trawls and dredge; hereafter "trawling") is important for global food security, providing about 20 million tonnes of global catch (Amoroso et al. 2018). However, the ecological impacts of trawling on the marine environment have been a concern across the globe (Jennings \& Kaiser, 1998; Puig et al., 2012; Pusceddu et al., 2014; Thrush \& Dayton, 2002). Overall, there is limited large-scale quantitative evidence of the risks trawling pose to the environment and to benthic organisms that encounter physical contact with trawl gear (Mazor et al., 2017; Pitcher et al., 2017).

Ecosystem-based management (EBM) is an approach that is being adopted around the globe for managing fisheries (Astles et al., 2006; Pikitch et al., 2004). This management approach considers the suite of interactions within a given ecosystem rather than addressing issues in isolation (Holsman et al., 2017). Risk assessment is an essential component of EBM and provides critical information for prioritizing management interventions (Holsman et al., 2017; Stelzenmüller et al., 2015). In the absence of a quantitative approach, there has typically been a reliance on qualitative risk assessments of seabed trawl impacts, using expert opinion and stakeholder knowledge, or rank scoring approaches to guide management decisions (Astles et al., 2006; Fletcher, 2005; Lorance et al., 2011). However, transparent evidence-based quantitative assessments are possible with access to technologies that provide information on fishing activity (e.g. Vessel Monitoring Systems (VMS) and satellite Automatic Identification Systems (AIS) for fishery effort information) and advances in statistical modelling methods (Pitcher et al., 2017).

Recent efforts have synthesized our current understanding of trawling extent and impacts around the world (Hiddink et al., 2017; Amoroso et al., 2018; Sciberras et al., 2018). For example, regional trawl footprint data were collated by Amoroso et al., (2018), providing a broad-scale spatial coverage of current trawl effort. The study found that $14.5 \%$ of the total studied area (7.7 million $\mathrm{km}^{2}$ ) was trawled, but varied considerably among 24 regions of the world. Systematic review methodologies and meta-analyses have been used to compile depletion and recovery information of trawl fishing disturbances on seabed invertebrates (Hiddink et al., 2017; Sciberras et al., 2018), highlighting those species groups that are more sensitive to trawl impacts (e.g. longlived biota; Hiddink et al., 2019). Given these advances, they now need to be applied to knowledge of spatial distributions of seabed fauna to assess the impact and sustainability of benthos in trawled regions.

Understanding the sensitivity of benthic invertebrates (benthos) to trawling disturbance is of fundamental ecological importance because they perform essential ecosystem processes such as reworking sediments, forming habitat structures and oxygenating the seafloor (Solan et al., 2004). Furthermore, their status is commonly used as an indicator for measuring ecosystem health or disturbance (Hiddink, Jennings, \& Kaiser, 2006; Przeslawski, Ahyong, Byrne, Wörheide, \& Hutchings, 2008). Despite their importance, knowledge of benthos distributions across broad spatial scales $\left(>1,000 \mathrm{~km}^{2}\right)$ is limited (Reiss et al., 2015); most likely attributable to high costs of surveys, limits in taxonomic expertise, and lengthy sample processing time (Fisher, Knowlton, Brainard, \& Caley, 2011). New methods have been proposed to predict and expand knowledge of spatial distributions of benthos at regional scales of 1,000's of km² (e.g. Baltic Sea: Gogina and Zettler (2010); North Sea: Reiss, Cunze, König, Neumann, and Kröncke (2011); Australian waters; Mazor et al. (2017)); these methods can be coupled with known distributions of trawl intensity to compute 


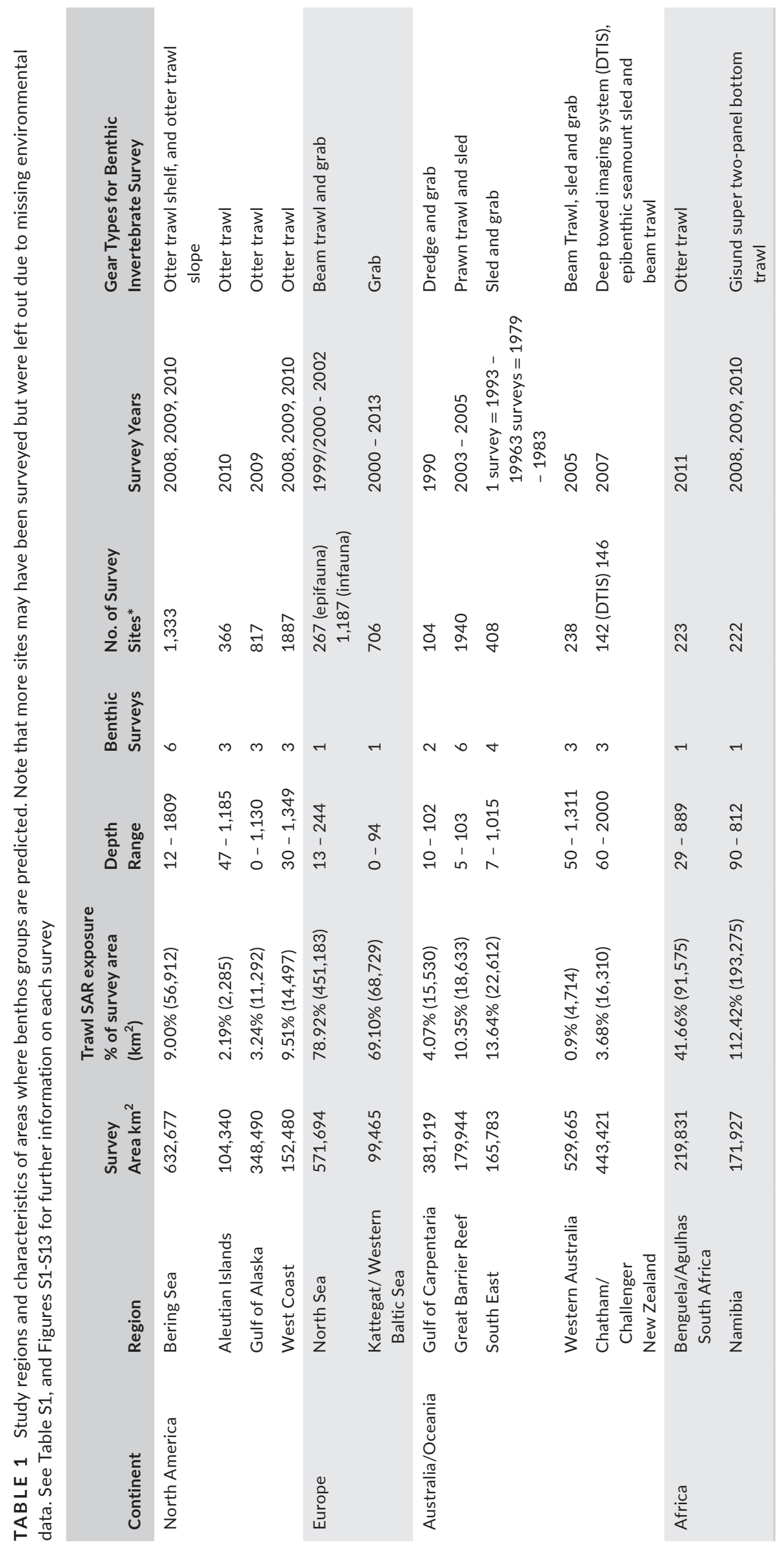


benthos status (relative to an untrawled state-calculated from impact rates, recovery rates and exposure to trawling) and help inform the extent to which trawling is sustainable in different areas of the seabed (Mazor et al., 2017). Combined, the information can be used assist managers in the choice of best practices to minimize impacts and ensure sustainability in the local context (McConnaughey et al., 2020).

Here, we quantify the status of benthos in 13 case-study regions from four continents (Australia, Europe, Africa and North America). Each region was chosen based on the availability of trawl intensity data and benthos survey data. To assess the status of benthos under current trawling practices, we modelled their current-day abundance distributions (based on recent survey samplings), and spatially combined these with maps of trawling intensity (Amoroso et al., 2018) and published recovery and depletion estimates derived from global meta-analyses (Hiddink et al., 2017; Sciberras et al., 2018; Hiddink et al., 2020), using a quantitative risk assessment method (Pitcher et al., 2017). Our findings aim to advance understanding of the current impacts and risks (to benthos) of trawling on the seafloor for regions across the globe.

\section{2 | METHOD}

\section{1 | Study regions}

Thirteen large-scale study regions across the globe were selected for analysis based on data availability (Table 1; Table S1). The geographical extent of each region was bounded by the latitude, longitude and depth range of the sites for which benthos data from systematic surveys were available to avoid excessive extrapolation of benthos predictions. For maps of study regions, see Figures S1-S13.

\section{2 | Trawl intensity}

Trawl intensity data were acquired from Amoroso et al., (2018). These data were calculated using VMS or fishing log-book data, to produce a swept area ratio (SAR: the annual cumulative area swept by trawl gear within a given grid cell of seabed, divided by the area of that grid cell) of trawling within a grid cell (either $1 \mathrm{~km}^{2}, 0.01^{\circ}$ or $1 \times 1$ min grids of longitude and latitude), over a 3- to 5-year period (typically 2008-2010). To ensure trawling activity is representative, we only included regions where $>70 \%$ of trawling activity was accounted for (Amoroso et al., 2018). To enable comparisons across regions where $<100 \%$ of trawling activity was reported, we scaled-up trawling effort ( $F$ by $100 /$ coverage\%) for each region and by gear type to represent total trawl intensity (i.e. 100\% trawl activity for each region), and recalculated regional SARs and footprints. This scaling and recalculation assumes that collated data are representative of the spatial distribution of the total.

\section{3 | Benthos distributions}

\subsection{1 | Benthos data}

Benthos data from seabed surveys were sought for regions where trawl intensity data were available from Amoroso et al., (2018). Ultimately, data were collated from 13 of 24 regions. Benthos abundances in surveys were recorded as counts or weight and were standardized by sampled area. We included surveys of both infauna and epifauna where possible and attempted to match survey years to the trawl data. Survey sampling gear varied among regions, but sampling was predominantly conducted using an otter trawl, benthic sled and/or grab (Table 1).

Eight taxonomic classes of benthos were examined: Anthozoa (i.e. sea anemones and corals), Ascidiacea (sea squirts), Asteroidea (seastars), Bivalvia (bivalved shelled molluscs), Gastropoda (sea snails and slugs (alt: coiled, conical or shell-less molluscs), Malacostraca (crabs and shrimps), Ophiuroidea (brittle stars) and Polychaeta (segmented worms). These classes were the subject of meta-analyses in which depletion and recovery information have recently been estimated (Hiddink et al., 2017; Sciberras et al., 2018; Hiddink et al., 2020; Figure 1). Following Mazor et al. (2017), we further divided taxonomic classes into benthos groups, that is, groups of species/taxa within a class that have similar spatial distributions and relationships with environmental variables. The clustering approach uses Multivariate Regression Trees (MRT) to group sites based on the sampled abundances of taxa and their relation with environmental variables, and assigns taxa to these site groups using the Dufrêne and Legendre (1997) indicator-species metric (DLI) (Mazor et al., 2017). Benthos groups were used because of inconsistencies in the level of reported taxonomic hierarchy among surveys and therefore serve as the lowest resolution of benthic data considered for this study.

\subsection{2 | Environmental predictors for modelling benthos}

Thirty-four environmental variables previously reported to be associated with distributions of a range of benthic invertebrates (Mazor et al., 2017) were used to model the distributions of benthos in each region (Table 2). All variables were available at a global extent at various spatial scales and were processed into consistent grids to match the resolution of the trawl intensity data provided for each region. Environmental layers (e.g. data from the NASA Ocean Biology Processing Group) were processed using R (R Core Team 2018; package "ncdf4"; Pierce, 2017, and package "raster" Hijmans 2019) to convert netCDF files into rasters. Annual averages for environmental variables were calculated from the monthly means of all available years. Seasonal range composites were calculated from the range of January to December monthly means, averaged across all years. All environmental variables (using raster format) 

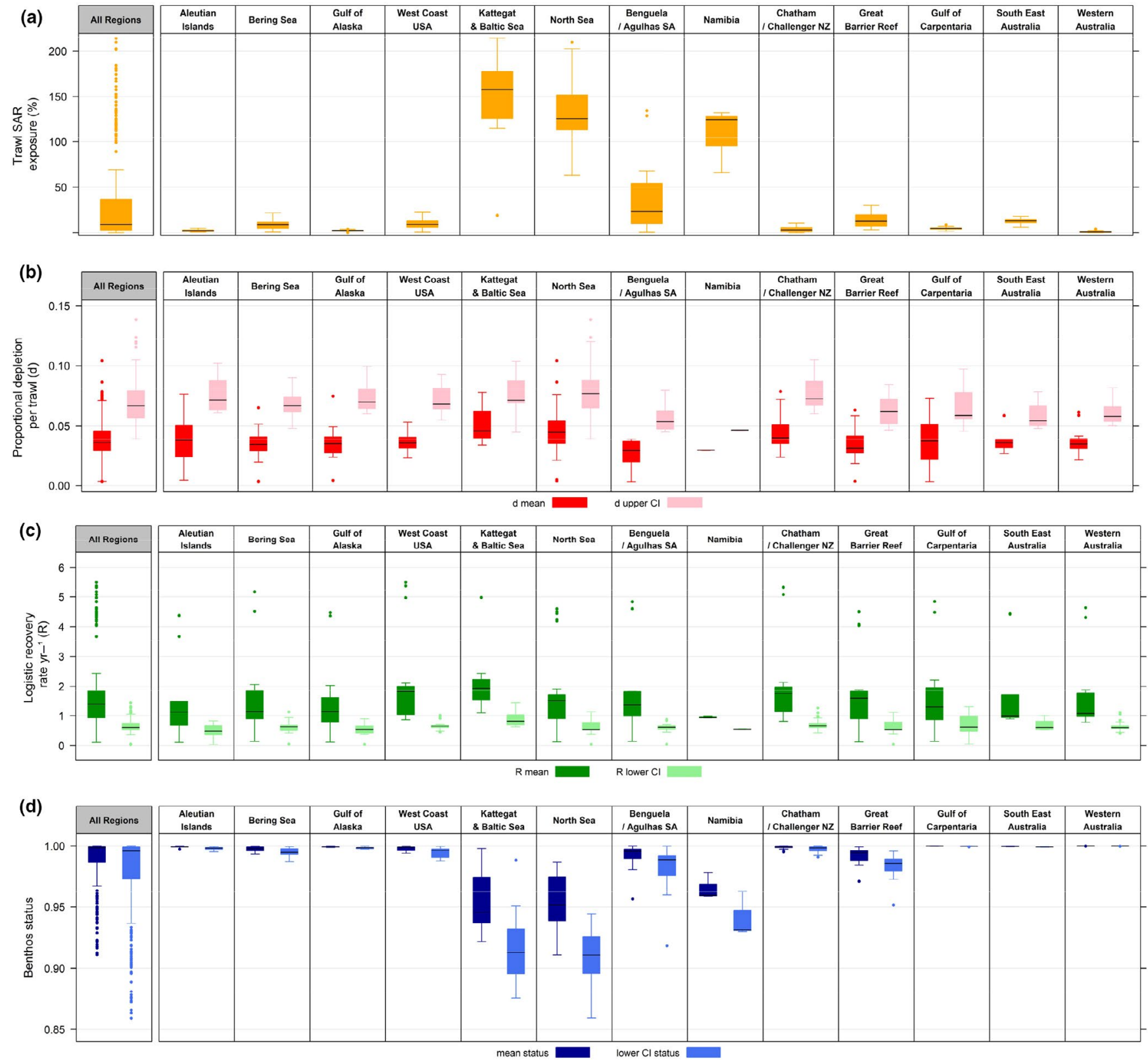

FIGURE 1 Box plots by region (Table S1 for more details) of: a) the percentage of benthos-group abundance exposed to trawling (SAR exposure), b) depletion values $d, \mathrm{c}$ ) recovery parameters $R, \mathrm{~d}$ ) the relative status of benthos groups using mean values and lower confidence interval for recovery. The black lines represent the median value

were transformed into the relevant projection and coordinate system (to match the gridded trawl intensity data) with resampling by cubic convolution to the desired cell size (either $1 \mathrm{~km}^{2}, 0.01^{\circ}$ or $1 \times 1$ min grids of longitude and latitude). Rasters were then clipped to the boundaries of each study region. Other environmental layers required three-dimensional interpolation to extract properties at the seafloor using a bathymetry layer (e.g. CSIRO Atlas of Regional Seas; Ridgway, Dunn, \& Wilkin, 2002). Predictors that did not vary among surveyed sites $(S D=0)$ or contained missing data for considerable parts of a region were excluded from individual analysis. Where predictors were largely complete (>90\% of grid), na.spline (package "zoo"; Zeileis, 2019) was used to interpolate missing predictor data.

\subsection{3 | Predicting benthos distributions}

Benthos-group abundance distributions were predicted for each region using R package "randomForest" (Liaw \& Wiener, 2002). For each region, we applied one of three methods to obtain a site-by-taxon matrix following Mazor et al. (2017): i) a single-gear approach-benthos were sampled by one device; abundance data were arranged into a conventional site-by-taxon matrix, ii) multiple gear approach-benthos were sampled by two different devices that sampled an overlapping composition of benthos at the same sites; a multiplicative scaling factor was estimated for each taxon sampled by different gears (note gear that targeted and predominantly sampled epifauna (e.g. trawls) and infauna (e.g. grabs) were not combined), and iii) disparate data sets 
TABLE 2 Thirty-four environmental variables used to predict benthos abundance distributions

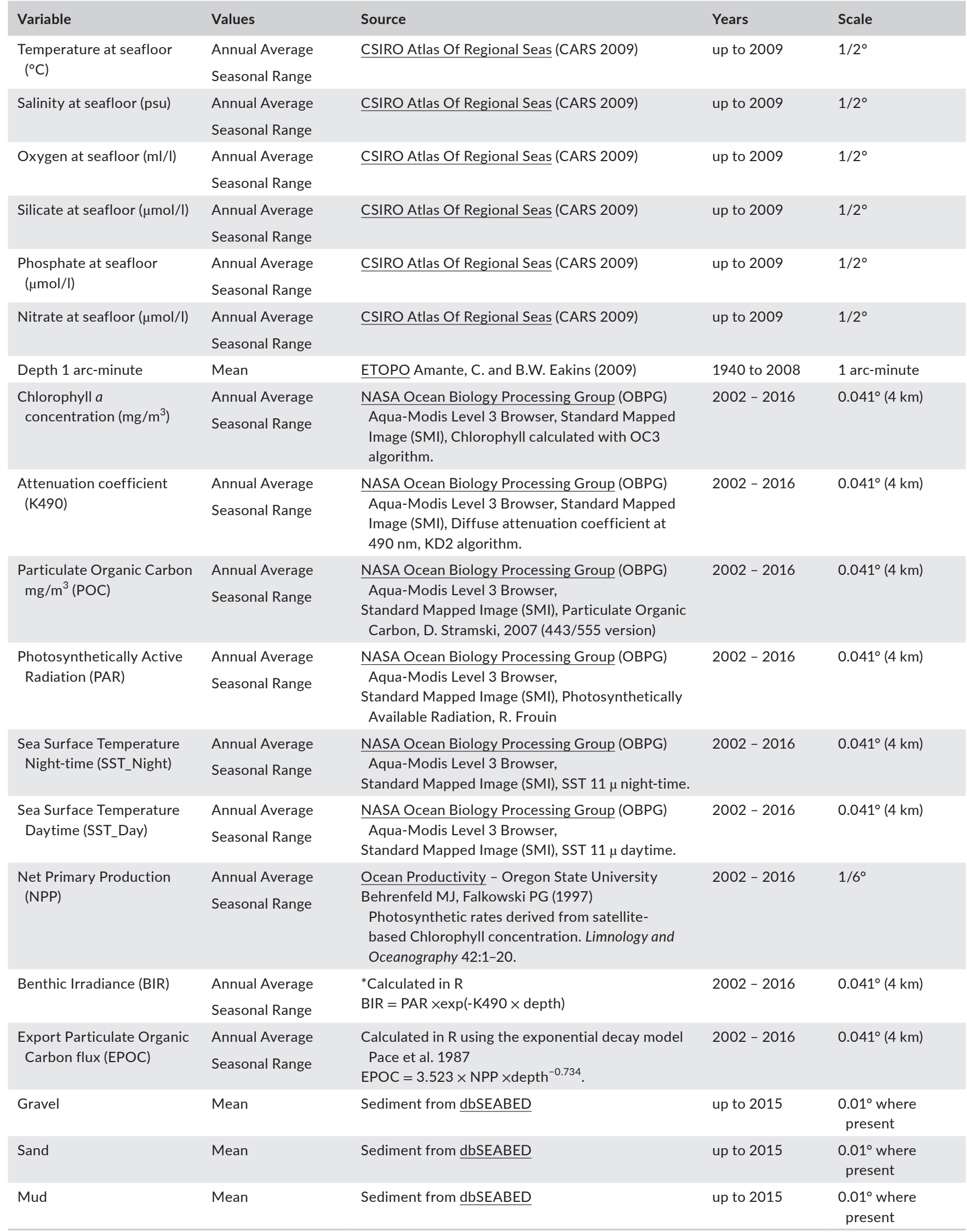


approach-benthos were sampled by multiple surveys disparate in one or more of spatial extent, time, taxonomic resolution and identification, sampling device and abundance metrics; in this case, random forest models predict taxa to unsampled sites combined with a scaling approach that normalizes taxa data to represent the proportion of abundance it contributes within its data sets.

Model performance was measured by the $R^{2}$ of overall fit of predicted against observed values and by the cross-validated outof-bag (OOB) $R^{2}$ values (estimated internally using bootstrapped samples that leave out about one-third of the data; Breiman, 2001). Predictor importance was extracted from the models as per Mazor et al., (2017) by obtaining the random forest predictor importance measure (\%IncMSE). Predictor importance across models was calculated by scaling importance by its proportionate contribution to model performance (OOB $R^{2}$ ) for each benthos group. These proportions were then averaged across all models, per region and per taxonomic class to estimate overall predictor importance. Models with poor prediction performance (cross-validated OOB $R^{2}<5 \%$ ) were excluded from the status assessment.

\section{4 | Trawl SAR exposure of predicted benthos distributions}

We quantified trawl SAR exposure (i.e. proportion of benthos abundance currently distributed in areas that are trawled) as a percentage, by spatially overlaying benthos-group distributions and trawl intensity (SAR). Specifically, we summed the product of the predicted benthos-group abundance in trawled grid cells multiplied by the trawl SAR of each cell and then divided by total group abundance in all cells, as per Mazor et al., (2017). We note that SAR exposure $>100 \%$ may occur for benthos abundance in cells with SAR $>1$ which are repeatedly exposed and thus the repeated exposure can be greater than the total abundance in all cells.

\subsection{Benthos status assessment model}

Here we applied a quantitative risk assessment method derived from the logistic population-growth equation (Pitcher et al., 2017) to estimate "relative benthos status" (RBS):

$$
\text { RBS }=1-F \frac{d}{r} \text {, }
$$

where $F$ is the trawling SAR, $d$ is trawl depletion rate per trawl pass, and $r$ is population growth/recovery rate. Depletion rate parameters, specific to taxonomic classes, were obtained from Sciberras et al. (2018, for trawl gears only), and recovery rates were derived from Hiddink et al., (2020), respectively (Table S2; see Supporting Information methods for details of derivation). Depletion rates also differ by trawl gear types and by habitats, and recovery rates also vary with habitat types. To account for this, taxonomic class-level average depletion and recovery rates were scaled according to gear types and habitat types (see Supporting Information methods). Absolute status, expressed as a proportion, was estimated from the product of RBS multiplied by the predicted abundance distribution (grid-cell abundances) and divided by the total benthos-group predicted abundance. A status of 1 indicates a state where the benthos population is not depleted by trawling and 0 being entire depletion. We characterized the uncertainty range in the status estimate by using the mean values for depletion and recovery, and by using the lower 95\% confidence interval $(\mathrm{Cl})$ for recovery. We used the lower $95 \% \mathrm{Cl}$ as it was considered more consistent with the concept of a precautionary approach. It was sufficient to use just the $\mathrm{Cl}$ for recovery without uncertainty in depletion because the uncertainties in these parameters are inversely related. Benthos status was also calculated to consider only trawled areas (grid cells with $F>0$ ) of our study regions to examine how status may change by spatial extent and specifically within trawled-only areas.

To investigate the relationship between traw SAR exposure and benthos status, we plotted the trawl SAR exposure, benthos status and sensitivity $(d / R)$ of each benthos group. Sensitivity $d$ (trawl depletion rate per trawl pass) and $R$ (population growth/recovery rate) was calculated as described in Supporting Information methods.

\section{3 | RESULTS}

\section{1 | Benthos distributions}

A total of 220 benthos-group distributions were modelled from our 13 study regions and 8 taxonomic classes (Table 3; Table S3). Average explanatory model performance across all benthos-group models, measured by the $\mathrm{R}^{2}$ of the overall fitted against observed values, was 0.75 (median $=0.82$ ), and the cross-validated $R^{2}$ of predicted against $O O B$ values was 0.37 (median $=0.34$ ). Model performance varied greatly by region (Figure S14), but not by taxonomic class (Figure S15). The most important predictors across all models were the seasonal range of photosynthetically active radiation (PAR), the average temperature at the seafloor $\left({ }^{\circ} \mathrm{C}\right)$, the average salinity at the seafloor (psu) and oxygen at the seafloor (ml/l) (Figures S16; S17). The pattern of predictor importance was highly variable across regions (Figure S16); however, some regions are particularly influenced by sediments, such as the Gulf of Carpentaria and the Great Barrier Reef. Predictor importance was less variable among taxonomic classes (Figure S17). Different benthos groups had different orders of predictor importance, but appeared more consistent across taxonomic classes compared to regions.

\section{2 | Trawl SAR exposure}

Across all regions, the mean percentage of the predicted abundance of benthos groups exposed to trawling was $36.63 \%$ (median $=8.90 \%$ ), with a range between $0 \%$ and $209.90 \%$ (Figure 1). The European regions, Kattegat/Western Baltic Sea and North Sea had the highest overlap of trawl activity with distributions of benthos, with an average exposure of $142.53 \%$ and $134.48 \%$, respectively. 
TAB LE 3 Number of derived benthos groups (method following Mazor et al., 2017) across region and per taxonomic class

\begin{tabular}{|c|c|c|c|c|c|c|c|c|c|}
\hline Region & $\begin{array}{l}\text { Benthos } \\
\text { Groups }\end{array}$ & Anthozoa & Ascidiacea & Asteroidea & Bivalvia & Gastropoda & Malacostraca & Ophiuroidea & Polychaeta \\
\hline Aleutian Islands & 10 & 1 & 2 & 2 & 1 & & 2 & 2 & \\
\hline Gulf of Alaska & 17 & 3 & 2 & 3 & 1 & 2 & 4 & 2 & \\
\hline $\begin{array}{l}\text { West Coast } \\
\text { USA }\end{array}$ & 17 & 3 & & 4 & & 3 & 4 & 3 & \\
\hline North Sea & 40 & 2 & 2 & 5 & 6 & 6 & 9 & 5 & 5 \\
\hline $\begin{array}{l}\text { Benguela/ } \\
\text { Agulhas South } \\
\text { Africa }\end{array}$ & 18 & 2 & 1 & 4 & & 2 & 4 & & \\
\hline $\begin{array}{l}\text { Great Barrier } \\
\text { Reef }\end{array}$ & 16 & 2 & 1 & 2 & 3 & 2 & 3 & 3 & \\
\hline $\begin{array}{l}\text { Gulf of } \\
\text { Carpentaria }\end{array}$ & 16 & 1 & 3 & 1 & 3 & 1 & 3 & 2 & 2 \\
\hline $\begin{array}{c}\text { South East } \\
\text { Australia }\end{array}$ & 13 & & & & 1 & 1 & 4 & 3 & 4 \\
\hline $\begin{array}{l}\text { Western } \\
\text { Australia }\end{array}$ & 18 & 2 & & 1 & 2 & 2 & 4 & 2 & 5 \\
\hline
\end{tabular}

The regions with moderate overlap were the African regions, Namibia (107.70\%) and Southern Benguela and Agulhas ecoregions of South Africa (37.57\%). Regions with the least overlap of trawling with benthos groups were Western Australia (1.13\%), Gulf of Alaska (2.32\%) and Aleutian Islands (2.41\%).

Among taxonomic classes, the range of trawl exposures (Figure 2a) was less than that among regions (Figure 1a). Taxonomic classes that had the highest mean percentage of their distributions overlapping with trawling across all regions were Bivalvia (55.70\%), Gastropoda (53.58\%) and Polychaeta (46.44\%) (Figure 2). The classes with the least trawl exposure were Anthozoa (20.52\%) and Ascidiacea (21.31).

\section{3 | Benthos status}

Across all benthos groups in all regions, the average status was 0.9878 (mean) and 0.9759 (lower Cl) (Figure 1,2). However, for individual benthos groups, status ranged from 0.9110 to 1 (mean), and 0.8592 to 1 (lower $\mathrm{Cl}$ ). The North Sea region had the lowest average status of 0.9538 (mean) and 0.9097 (lower $\mathrm{Cl}$ ), followed by the Kattegat/Western Baltic Sea (0.9554 mean; 0.9189 lower $\mathrm{Cl}$ ) (Figure 1d,3). These regions also had the largest range of status (max-min). The majority of regions (8 of 13) had an average status $>0.99$ (both mean and lower $\mathrm{Cl}$ values; Figure 3), whereas for taxonomic classes, only half of the benthos groups had an average status $>0.98$ (both mean and lower $\mathrm{Cl}$ values; Figure $2 \mathrm{~d}$ ). The class Bivalvia had the lowest average status (0.9738 mean; 0.9587 lower $\mathrm{Cl}$ ), followed by Malacostraca (0.9841 mean; 0.9742 lower $\mathrm{CI}$ ) and Gastropoda (0.9895 mean; 0.9718 lower CI). Similarly to regions, taxonomic classes with the lowest average status also had the largest range of values. Benthos status when calculated for only trawled areas (grid cells with SAR $>0$ ) of our study regions (Figure S18; Table S3) were slightly lower (range from 0.8754 to 0.9999 , and lower $\mathrm{Cls}$ from 0.8020 to 0.9999 ; average status 0.9807 and 0.9610 (lower $\mathrm{Cl}$ )) compared to benthos status for our entire study regions (Figure 1) (means ranging from 0.9110 to 1 , and lower $\mathrm{Cls}$ from 0.8592 to 1 ).

We found that higher trawl SAR exposure was related to a lower benthos-group status ("lower" in relation to our resultswhere status 0.98 was the lower confidence interval) (Figure 4). Benthos status also depended on the sensitivity $(d / R)$ of the benthos group to trawling impacts and their ability to recover. Sensitivity ranged from 0.0076 to 0.0697 , and higher sensitivity to trawling (dark points on Figure 4) was related to a lower benthos status. However, this relationship did vary and some groups in Europe with higher sensitivity have greater exposure to beam trawls and dredges; the spatial footprints of these gear types are 

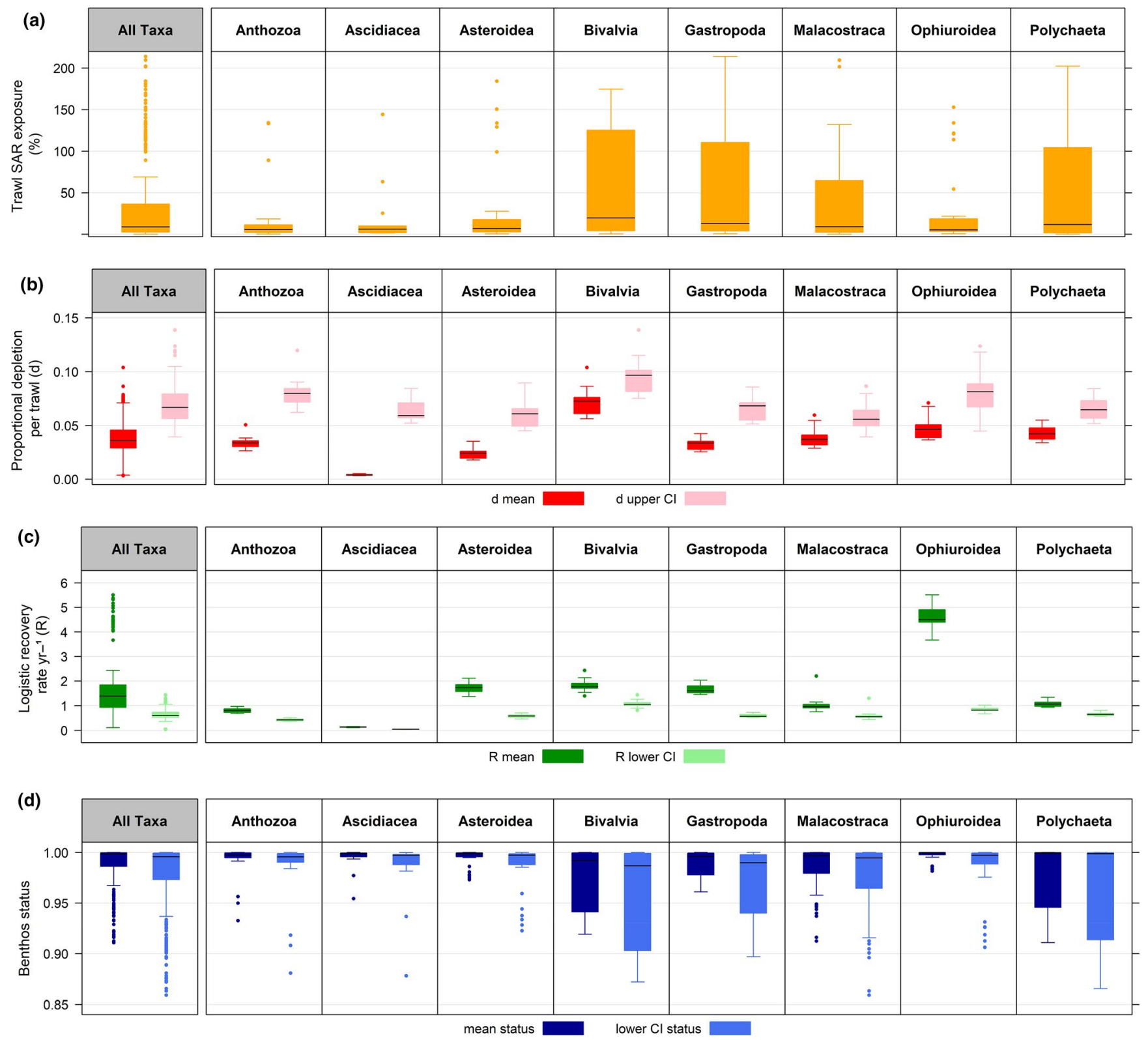

FIGURE 2 Box plots by taxonomic class (Table 3 for more details) of a) the percentage of benthos-group abundance exposed to trawling (SAR exposure) b) depletion values $d, \mathrm{c}$ ) recovery parameters $R, d$ ) the relative benthos status using mean values and lower confidence interval for recovery. The black lines represent the median value

narrower than those of otter trawls and thus contribute less to cell SAR but lead to higher depletion rates (d). Other factors that prevent a strict relationship with sensitivity are that distributions of benthos groups and of trawling (and different gear types) are complex and differ with sediment distributions.

\section{4 | DISCUSSION}

This study presents a large-scale assessment of the status of seabed invertebrate communities and provides insight into the sustainability of bottom trawling in regions across the globe. Unlike other largescale assessments that have examined trawl footprints (Amoroso et al., 2018), or status of sedimentary habitats in relation to trawling (Pitcher et al., in review), this work incorporates sampling data from surveys of benthos enabling a more direct quantification of trawl impacts on different types of benthos. Our results indicate that benthos groups may have up to $210 \%$ of their distribution exposed to trawl activity (as SAR intensity), yet the lowest benthos status at a regional scale was 0.86 , decreasing to 0.80 within trawled footprint areas (Figure S18). In 11 of our 13 case-study regions, all benthos groups had a status $>0.95$, and only a quarter (22\%) of benthos groups had a status $<0.95$ (i.e. reduced by $0.05-0.14$ owing to trawling activity). Overall benthos status was relatively high (mean status $=0.99$; lower confidence interval $=0.98$; mean status in trawled areas $=0.98$; lower confidence interval in trawled areas $=0.96$ ) 

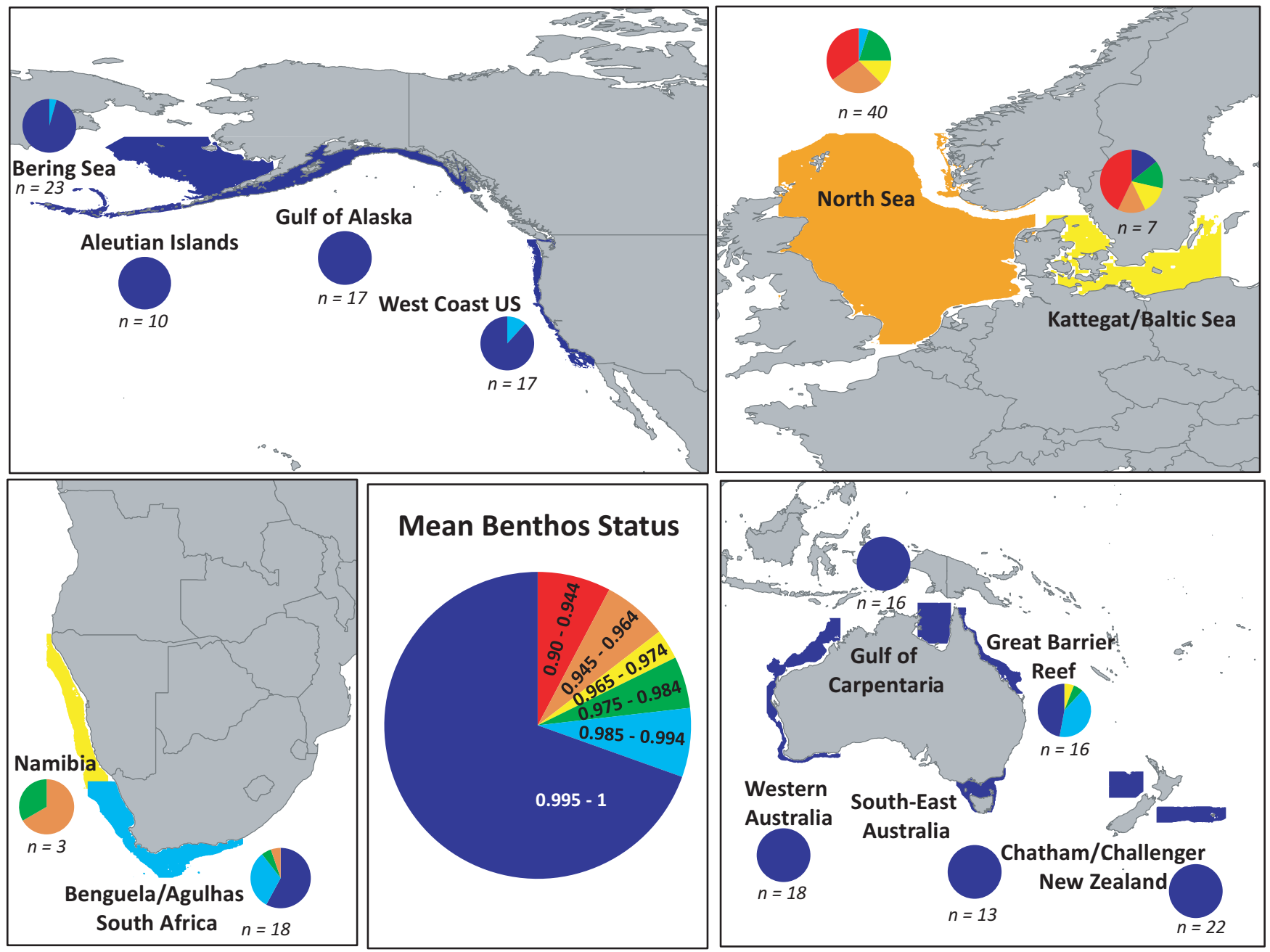

FIGURE 3 Map of mean benthos-group status across 13 case-study regions (for study region maps, see Figure S1-S13). For each region, $n$ is the total number of benthos groups assessed, and pie charts represent the proportion of benthos groups with a particular benthos statuscoloured according to the overall mean benthos status pie chart. Figure appears in colour in the online version only

Hence, regional-scale impacts of trawling on the seabed communities assessed in this study seemed less than might be expected from results of previous studies (Hiddink et al., 2017; Amoroso et al., 2018; Sciberras et al., 2018).

European regions (the North Sea and Skagerrak/Kattegat) have trawl footprints covering > 50\% of their continental shelf (Amoroso et al., 2018) and had the lowest average benthos status between 0.95-0.96 (Figure 3). Regions of Africa with trawl footprints of $\sim 10 \%-30 \%$ of their continental shelves (Amoroso et al., 2018) displayed an average benthos status between 0.97-0.99 (Figure 3). Regions, such as North America and Australia, with lower trawl footprints $(<10 \%)$ displayed higher benthos status (i.e. $>0.99$ ). Although average benthos status per region relates to the overall trawl SAR exposure, there are differences for particular benthos groups due to their sensitivity to trawling (Figures 1, 4). For example, average benthos status for the North Sea region was 0.95, but one Bivalvia group had a lower status of 0.92 due to higher trawl exposure (174.64\%) and sensitivity (0.04) (Figure 5a).
Spatial overlays of human activities on habitats or species distribution maps are often used to infer threats and risks (Evans et al., 2011; Trebilco et al., 2011) and can be informative for prioritizing areas where there is greater potential risk of impact, and for indicating where more information is needed (Ban, Alidina, \& Ardron, 2010). However, our results show that while there is a general trend that greater overlaps of benthos distributions with trawling result in lower benthos status (Figure 4), the rates of impact and the recovery rates (sensitivity; Table S3) of organisms are also important (Pitcher, 2014). Simple spatial overlap analyses that do not consider these dynamics are problematic for determining specific management actions (Tulloch et al., 2015). For example, Benguela/ Agulhas South Africa's Asteroidean group has considerably higher trawl exposure (129.32\%) than the Great Barrier Reef Malacostraca group (15.19\%), yet their status is relatively similar $(0.9864$ and 0.9849 , respectively; Figure 5$)$. This similarity is due to the higher recovery $(R=1.81)$ and thus lower sensitivity (0.01) to trawl impacts for Benguela/Agulhas South Africa's Asteroidea in comparison to the higher sensitivity (0.03) for Malacostraca in the Great Barrier 


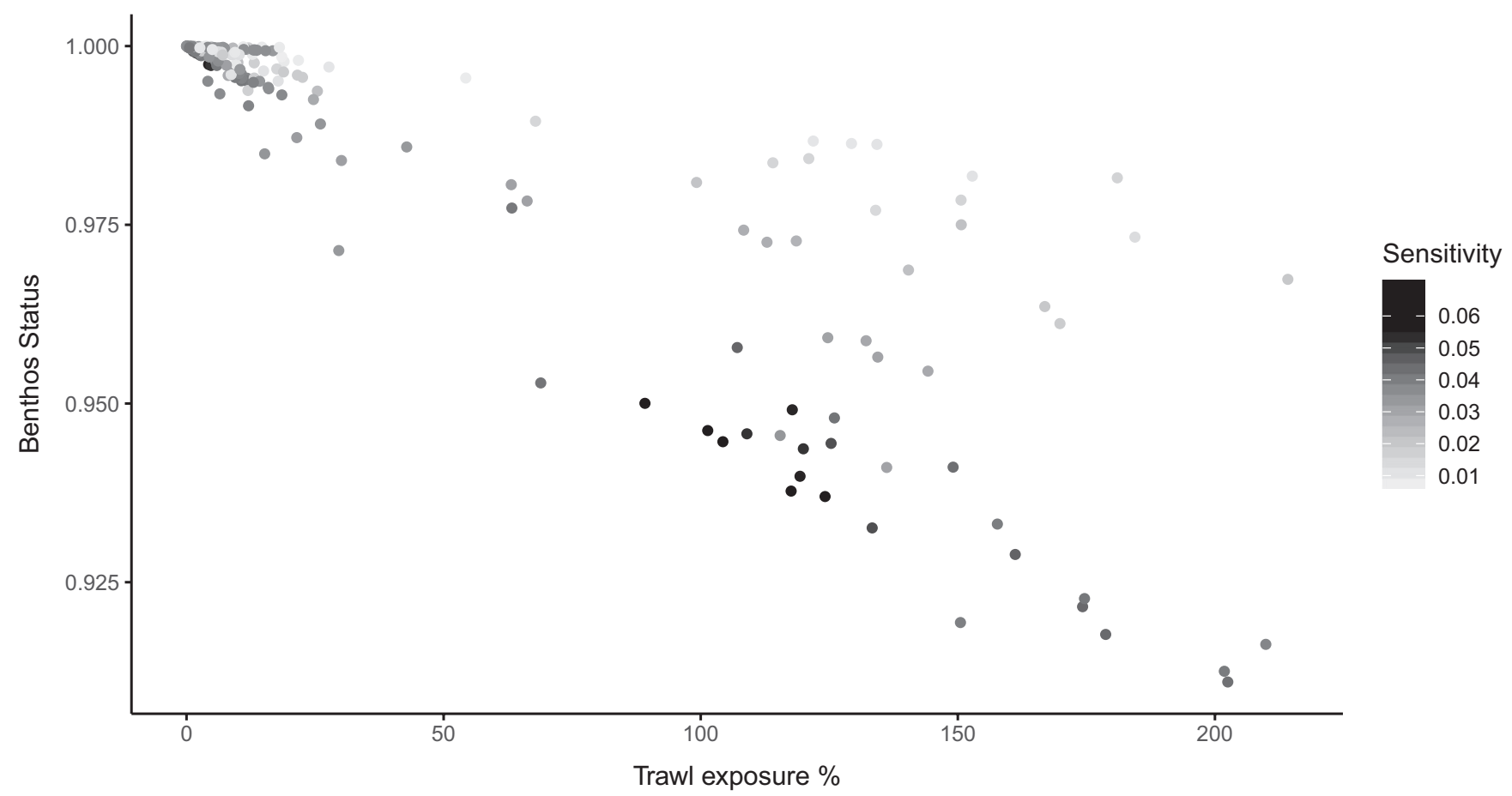

FIGURE 4 Relationship between benthos status (mean values) and trawl SAR exposure (Table S3). Each point represents a predicted benthos group $(n=220)$, and sensitivity $(d / R)$, where $d$ (trawl depletion rate per trawl pass) and $R$ (population growth/recovery rate) is calculated as described in Supporting Information methods

Reef. Thus, when quantifying risks, the dynamics of biological processes (e.g. the depletion and recovery component in our assessment model) need to be incorporated, as presented in this study, to avoid misdirecting management actions and to ensure effective outcomes.

Comparisons across regions and taxa are complex when different quantities and sources of data are used. For instance, our study indicates that the taxonomic class Bivalvia has a slightly lower benthos status than other classes. However, this may be related to the higher number of bivalve groups located in heavily trawled regions of Europe. Likewise, for Namibia, our results are based only on three Malacostraca groups, as these were the only taxa for which data were available for the region. It is likely that the average benthos status calculated for this region is not representative of other benthos taxa. Species distribution model performance also ranged widely among regions, with poorer performance in some regions such as the Aleutian Islands and Kattegat/Western Baltic Sea (Figure S14). Differences in performance are possibly related to the range of taxa or environmental variables in each region, where model performance has been found to be higher for taxa with narrower environmental gradients compared to those with larger areas of occupancy (Grenouillet, Buisson, Casajus, \& Lek, 2011). Other caveats of this study include the spatial scale of benthic surveys, where some countries sampled the same or similar spatial extents to that of their trawl fishery grounds, while others have used a broader regional approach (Figures S1 - S13). This may lead to indications of greater relative trawl exposure and lower status in the former and the opposite in the latter, simply due to study extent. To address this issue, we also provided benthos status for trawled-only areas (only for grid cells with SAR > 0) and found comparable results with only a slight decrease of benthos status within trawled-only areas in comparison to our full study area extents (Figure S18). Lower benthos status may also occur if this study attempted to predict relative to a pristine pretrawled baseline as many regions have had long histories of trawling which is likely to have modified benthic community composition and distribution. It is important to note that we have only considered eight common taxonomic classes and have not included biogenic habitats or most types of colonial organisms (e.g. bryozoans, porifera and hydrozoans). These organisms are expected to be more sensitive to trawling (Althaus et al., 2009; Collie, Hall, Kaiser, \& Poiner, 2000) and, depending on how they are distributed in relation to where trawling occurs, would likely have a lower benthos status than the classes of biota assessed in this study. For example, Anthozoa and Ascidiacea had lower trawl exposure as such species are commonly found on hard substrata that are less exposed to trawling (Lambert, Jennings, Kaiser, Hinz, \& Hiddink, 2011; Pitcher et al., 2016). Benthos data in this study were predominantly sampled in unconsolidated habitat types that are conducive to survey by trawl gears; thus, our outcomes will not reflect benthos in hard ground habitats which may be more sensitive (Lambert et al., 2011). Nevertheless, some limitations are inherent when conducting broad-scale, multiregional studies, that are dependent on existing available data.

Overall, our study presents the most comprehensive and extensive quantitative synthesis of information regarding the status of benthos invertebrate communities in multiple regions worldwide. We highlight the importance of quantifying benthos status for environmental risk assessments in comparison to simpler spatial overlap 


\section{Distribution}

(a)

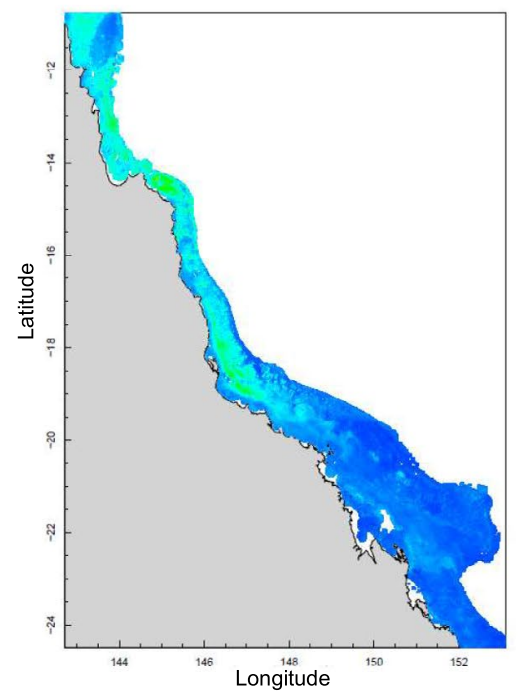

(b)

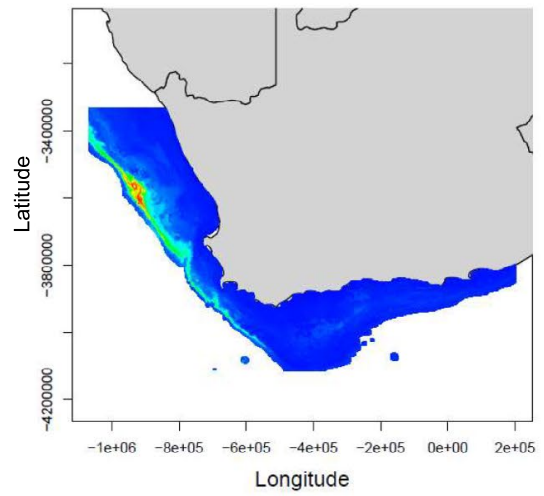

(c)

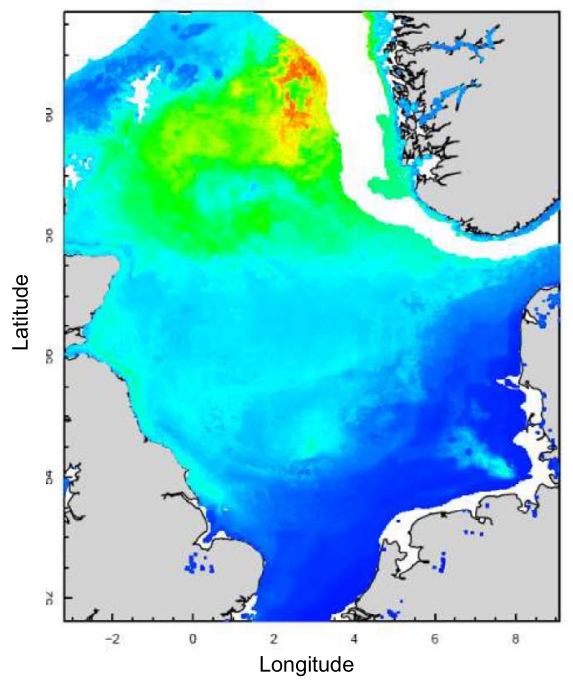

Impact

\section{Status}
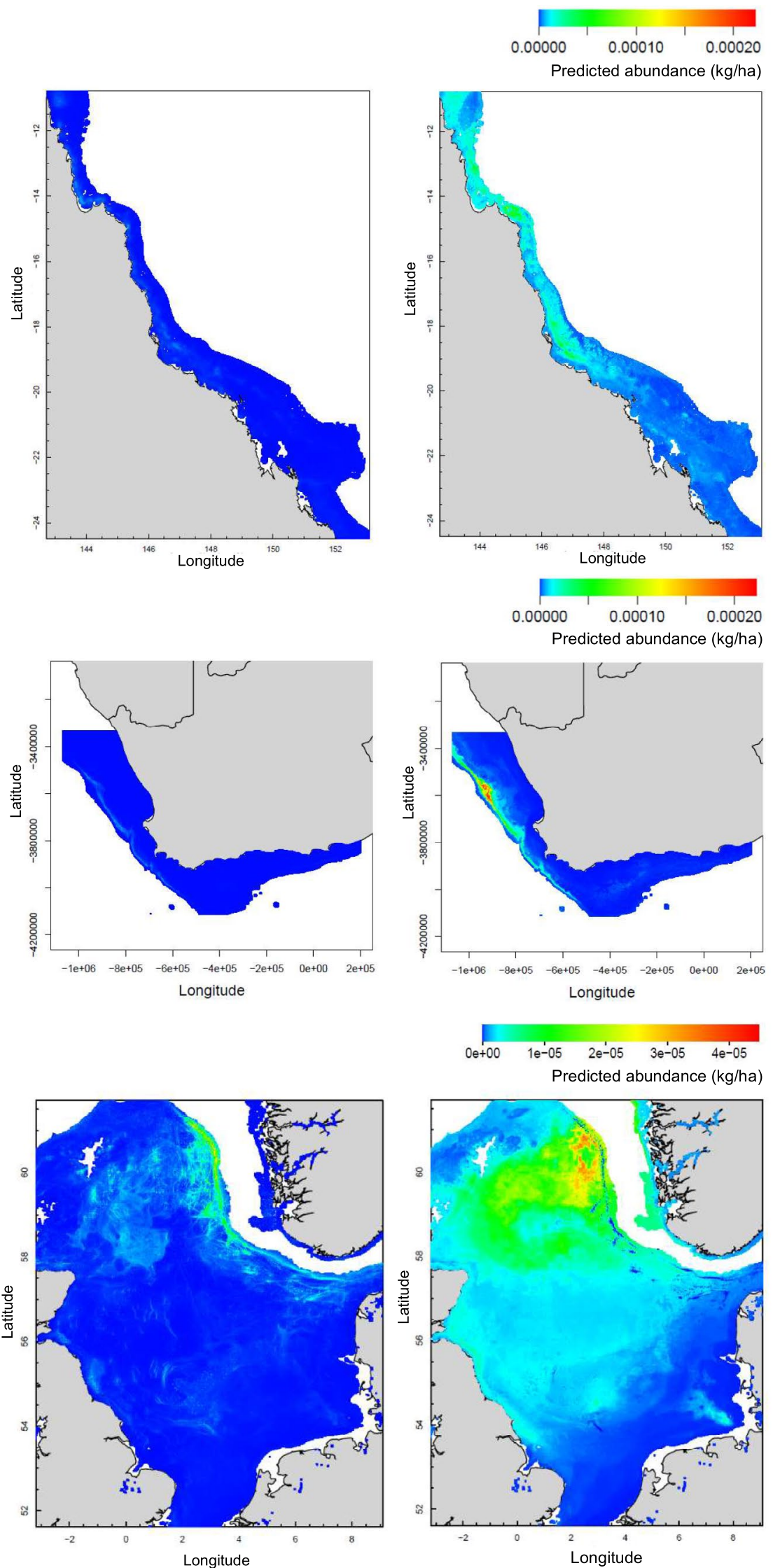
FIGURE 5 Three case-study examples of benthos groups a) North Sea bivalve group (infauna) (trawl SAR exposure 174.64\%, benthos status 0.92), b) Benguela/Agulhas South African asteroidean group (trawl SAR exposure 129.32\%, benthos status 0.99), c) Great Barrier Reef malacostraca group (trawl SAR exposure 15.19\%, benthos status 0.98). For each region showing (left to right) the predicted abundance distribution of the benthos group, distribution of impacted abundance, and predicted benthos status distribution. Figure appears in colour in the online version only

only approaches. Our results demonstrate that, while there is a broad relationship between trawl SAR exposures and benthos status, exposure alone is not sufficient to account for benthos status or for implementing risk assessments and management decisions at regional or local scales, where adequate benthos distribution and sensitivity data (trawl impact and recovery) are available. Our study encompasses multiple regions across the globe where trawling occurs at a range of intensities and extents. However, other regions where trawl intensity is known to be higher, such as the Mediterranean Sea and South East Asia (FAO 2014; Amoroso et al., 2018; Suuronen et al., 2020), could not be included due to lack of available benthos survey data. For such regions where data (benthic or otherwise) are limited, are of poor quality (e.g. low resolution) or their acquisition is difficult, we may need to rely on coarser methods of estimating trawl risks. For example, using the broader patterns observed by spatial overlap studies, trawl exposure measures, maximum sustainable yield reference points (Fmsy), habitat status assessments (Pitcher et al., in review) or regional SARs (ratio of total swept area trawled annually to total area of region; Amoroso et al., 2018). Ideally, more benthos surveys in heavily trawled regions are needed and integrated approaches where multiple stakeholders (e.g. governmental, academic, industrial) contribute to marine benthic monitoring (Barrio-Froján et al., 2016) may offer a possible solution for better quantifying the state of the seabed in trawled areas of the world's oceans.

Findings from this study, and broader application of the approaches used in this study, will enable environmental managers to identify which regions and taxa are at greatest risk of unsustainable trawling regimes. Ideally, these assessments will need to be coupled with reference points and thresholds that indicate risk (e.g. Lambert et al., 2017). For example, is a regional benthos status of 0.95 acceptable to stakeholders and the wider community? What are the cascading effects of such a status on the wider marine ecosystem? Reference points for benthic invertebrates are undeveloped and will require further research to determine them, which will likely be specific to a given region (Couce, Engelhard, \& Schratzberger, 2019; Lambert et al., 2017). However, the specificity of the status information provides useful quantitative guidance for implementing management measures to mitigate the impacts (McConnaughey et al., 2020). We suggest that such topics need to be the focus of future research to support the growing commitment for countries around the globe to implement ecosystem-based management (EBM) principles and practices, and to manage fisheries in a manner that is sustainable for marine ecosystems.

\section{ACKNOWLEDGEMENTS}

T. Mazor was supported during her research by a CSIRO Postdoctoral Fellowship and CSIRO Ruby Payne-Scott Award. All authors acknowledge their organizations for salary support; the Walton Family
Foundation and the David and Lucile Packard Foundation, Food and Agriculture Organization of the United Nations, and fishing industry organizations for funding of workshops and travel; C. Jenkins for dbSEABED sediment data; D. Bowden for New Zealand benthic survey data; regional fishery management agencies for trawl effort and benthic faunal survey data (Table S1). The findings and conclusions in the paper are those of the authors and do not necessarily represent the views of the National Marine Fisheries Service.

\section{DATA AVAILABILITY STATEMENT}

The underlying data used in this paper are available at https://trawl ingpractices.wordpress.com/datasets/. All other data needed to repeat the analyses in the paper are presented in the paper or the supporting information, or published in cited articles and reports.

\section{ORCID}

Tessa Mazor iD https://orcid.org/0000-0001-7307-5693

C. Roland Pitcher http://orcid.org/0000-0003-2075-4347

Wayne Rochester (ID https://orcid.org/0000-0002-7315-9341

Michel J. Kaiser http://orcid.org/0000-0001-8782-3621

Jan G. Hiddink http://orcid.org/0000-0001-7114-830X

Simon Jennings (iD https://orcid.org/0000-0002-2390-7225

Robert A. McConnaughey (iD https://orcid.org/0000-0002-8537-3695

Adriaan D. Rijnsdorp (iD https://orcid.org/0000-0003-0785-9662

Ana M. Parma iD https://orcid.org/0000-0003-0461-2904

Petri Suuronen http://orcid.org/0000-0001-7743-4091

Marija Sciberras (iD https://orcid.org/0000-0002-4319-3522

Stefan G. Bolam (iD https://orcid.org/0000-0001-6604-4741

Michaela Schratzberger (iD https://orcid.org/0000-0002-4973-6698

Paulus Kainge iD https://orcid.org/0000-0003-4498-9845

P. Daniël van Denderen iD https://orcid.org/0000-0001-6351-0241

Ray Hilborn http://orcid.org/0000-0003-2326-2305

Jim Ellis iD https://orcid.org/0000-0002-8851-7965

Elena Couce (iD https://orcid.org/0000-0002-3945-462X

Jacqueline Eggleton (iD https://orcid.org/0000-0001-5850-3813

Clement Garcia iD https://orcid.org/0000-0001-5916-8914

\section{REFERENCES}

Althaus, F., Williams, A., Schlacher, T. A., Kloser, R. J., Green, M. A., Barker, B. A., ... Schlacher-Hoenlinger, M. A. (2009). Impacts of bottom trawling on deep-coral ecosystems of seamounts are long-lasting. Marine Ecology Progress Series, 397, 279-294. https://doi.org/10.3354/ meps08248

Amoroso, R. O., Pitcher, C. R., Rijnsdorp, A. D., McConnaughey, R. A., Parma, A. M., Suuronen, P., ... Althaus, F. et al (2018). Bottom trawl fishing footprints on the world's continental shelves. Proceedings of the National Academy of Sciences, 115, E10275-E10282. https://doi. org/10.1073/pnas.1802379115

Astles, K., Holloway, M., Steffe, A., Green, M., Ganassin, C., \& Gibbs, P. (2006). An ecological method for qualitative risk assessment and its 
use in the management of fisheries in New South Wales, Australia. Fisheries Research, 82, 290-303. https://doi.org/10.1016/j.fishr es.2006.05.013

Ban, N. C., Alidina, H. J., \& Ardron, J. A. (2010). Cumulative impact mapping: Advances, relevance and limitations to marine management and conservation, using Canada's Pacific waters as a case study. Marine Policy, 5, 876-886. https://doi.org/10.1016/j.marpol.2010.01.010

Barrio-Frojan, C., Cooper, K. M., \& Bolam, S. G. (2016). Progress towards a unified approach to monitoring across the UK. Marine Pollution Bulletin, 104, 20-28.

Breiman, L. (2001). Random Forests. Machine Learning, 45(1), 5-32.

Collie, J. S., Hall, S. J., Kaiser, M. J., \& Poiner, I. R. (2000). A quantitative analysis of fishing impacts on shelf-sea benthos. Journal of Animal Ecology, 69, 785-798. https://doi.org/10.1046/j.1365-2656.2000.00434.x

Couce, E., Engelhard, G. H., \& Schratzberger, M. (2019). Capturing threshold responses of marine benthos along gradients of natural and anthropogenic change. Journal of Applied Ecology, 10, 1072-1082. https://doi.org/10.1111/1365-2664.13604

Dufrêne, M., \& Legendre, P. (1997). Species assemblages and indicator species: The need for a flexible asymmetrical approach. Ecological Monographs, 67, 345-366. https://doi.org/10.1890/00129615(1997)067[0345:SAAIST]2.0.CO;2

Evans, M. C., Watson, J. E., Fuller, R. A., Venter, O., Bennett, S. C., Marsack, P. R., \& Possingham, H. P. (2011). The spatial distribution of threats to species in Australia. BioScience, 61, 281-289. https://doi. org/10.1525/bio.2011.61.4.8

FAO. (2014). APFIC/FAO Regional Expert Workshop on "Regional guidelines for the management of tropical trawl fisheries in Asia". Phuket, Thailand, 30 September-4 October 2013. FAO Regional Office for Asia and the Pacific, Bangkok, Thailand. RAP Publication 2014/01, pp 91.

Fisher, R., Knowlton, N., Brainard, R. E., \& Caley, M. J. (2011). Differences among major taxa in the extent of ecological knowledge across four major ecosystems. PLoS One, 6, e26556. https://doi.org/10.1371/ journal.pone.0026556

Fletcher, W. J. (2005). The application of qualitative risk assessment methodology to prioritize issues for fisheries management. ICES Journal of Marine Science, 62, 1576-1587. https://doi.org/10.1016/j. icesjms.2005.06.005

Gogina, M., \& Zettler, M. L. (2010). Diversity and distribution of benthic macrofauna in the Baltic Sea: Data inventory and its use for species distribution modelling and prediction. Journal of Sea Research, 64, 313-321. https://doi.org/10.1016/j.seares.2010.04.005

Grenouillet, G., Buisson, L., Casajus, N., \& Lek, S. (2011). Ensemble modelling of species distribution: The effects of geographical and environmental ranges. Ecography, 34, 9-17. https://doi. org/10.1111/j.1600-0587.2010.06152.x

Hiddink, J. G., Jennings, S., \& Kaiser, M. J. (2006). Indicators of the Ecological Impact of Bottom-Trawl Disturbance on Seabed Communities. Ecosystems, 9, 1190-1199. https://doi.org/10.1007/ s10021-005-0164-9

Hiddink, J. G., Jennings, S., Sciberras, M., Bolam, S. G., Cambiè, G., McConnaughey, R. A., ... Rijnsdorp, A. D. (2019). Assessing bottom trawling impacts based on the longevity of benthic invertebrates. Journal of Applied Ecology, 56, 1075-1084. https://doi. org/10.1111/1365-2664.13278

Hiddink, J. G., Jennings, S., Sciberras, M., Szostek, C. L., Hughes, K. M., Ellis, N., ... Kaiser, M. J. (2017). Global analysis of depletion and recovery of seabed biota after bottom trawling disturbance. Proceedings of the National Academy of Sciences, 114, 8301-8306. https://doi. org/10.1073/pnas.1618858114

Hiddink, J. G., Kaiser, M., Sciberras, M., McConnaughey, R. A., Mazor, T., \& Hilborn, R. ... Jennings, S. (2020). Selection of indicators for assessing and managing the impacts of bottom trawling on seabed habitats. Journal of Applied Ecology, 57, 1199-1209.
Hijmans, R. J. (2019). Package 'raster'; Geographic Data Analysis and Modeling. R package version 2.9-5. Retrieved from https:// cran.r-project.org/web/packages/raster/raster.pdf

Holsman, K., Samhouri, J., Cook, G., Hazen, E., Olsen, E., Dillard, M., ... Andrews, K. (2017). An ecosystem-based approach to marine risk assessment. Ecosystem Health and Sustainability, 3, e01256. https://doi. org/10.1002/ehs2.1256

Jennings, S., \& Kaiser, M. J. (1998). The Effects of Fishing on Marine Ecosystems. Advances in Marine Biology, 34, 201-352. https://doi. org/10.1016/S0065-2881(08)60212-6

Lambert, G. I., Jennings, S., Kaiser, M. J., Hinz, H., \& Hiddink, J. G. (2011). Quantification and prediction of the impact of fishing on epifaunal communities. Marine Ecology Progress Series, 430, 71-86. https://doi. org/10.3354/meps09112

Lambert, G. I., Murray, L. G., Hiddink, J. G., Hinz, H., Lincoln, H., Hold, N., ... Kaiser, M. J. (2017). Defining thresholds of sustainable impact on benthic communities in relation to fishing disturbance. Scientific Reports, 7, 1-15. https://doi.org/10.1038/s41598-017-04715-4

Liaw, A., \& Wiener, M. (2002). Classification \& regression by randomForest. $R$ News, 2, 18-22.

Lorance, P., Agnarsson, S., Damalas, D., Des Clers, S., Figueiredo, I., Gil, J., \& Trenkel, V. M. (2011). Using qualitative and quantitative stakeholder knowledge: Examples from European deep-water fisheries. ICES Journal of Marine Science, 68, 1815-1824. https://doi. org/10.1093/icesjms/fsr076

Mazor, T. M., Pitcher, C. R., Ellis, N., Rochester, W., Jennings, S., Hiddink, J. G., ... Hilborn, R. (2017). Trawl Exposure and Protection of Seabed Fauna at Large Spatial Scales. Diversity and Distributions, 23, 12801291. https://doi.org/10.1111/ddi.12622

McConnaughey, R. A., Hiddink, J. G., Jennings, S., Pitcher, C. R., Kaiser, M. J., Suuronen, P., ... Hilborn, R. (2020). Choosing best practices for managing impacts of trawl fishing on seabed habitats and biota. Fish and Fisheries, 21, 319-337. https://doi.org/10.1111/faf.12431

Pierce, D. (2017). Package 'ncdf4'; Interface to Unidata netCDF (Version 4 or Earlier) Format Data. R Package Version, 1(16), 1. Retrieved from https://cran.r-project.org/web/packages/ncdf4/ncdf4.pdf

Pikitch, E. K., Santora, C., Babcock, E. A., Bakun, A., Bonfil, R., Conover, D. O., ... Sainsbury, K. J. (2004). Ecosystem-Based Fishery Management. Science, 305, 346-347. https://doi.org/10.1126/science.1098222

Pitcher, C. R. (2014). Quantitative indicators of environmental sustainability risk for a tropical shelf trawl fishery. Fisheries Research, 151, 136-147. https://doi.org/10.1016/j.fishres.2013.10.024

Pitcher, C. R., Ellis, N., Jennings, S., Hiddink, J. G., Mazor, T., Kaiser, M. J., ... Hilborn, R. (2017). Estimating the sustainability of towed fishing-gear impacts on seabed habitats: A simple quantitative risk assessment method applicable to data-limited fisheries. Methods in Ecology and Evolution, 8, 472-480. https://doi.org/10.1111/2041-210X.12705

Pitcher, C. R., Ellis, N., Venables, W. N., Wassenberg, T. J., Burridge, C. Y., Smith, G. P., ... Gribble, N. (2016). Effects of trawling on sessile megabenthos in the Great Barrier Reef and evaluation of the efficacy of management strategies. ICES Journal of Marine Science, 73, 115-126. https://doi.org/10.1093/icesjms/fsv055

Pitcher, C. R., Hiddink, J. G., Jenning, S., Amoroso, R., Mazor, T., Rijinsdorp, A. D., ... Hilborn, R. (in review). Trawl impacts on seabed habitat status in 24 regions of the world.

Przeslawski, R., Ahyong, S., Byrne, M., Wörheide, G., \& Hutchings, P. (2008). Beyond corals and fish: The effects of climate change on noncoral benthic invertebrates of tropical reefs. Global Change Biology, 14, 2773-2795. https://doi.org/10.1111/j.1365-2486.2008.01693.x

Puig, P., Canals, M., Company, J. B., Martin, J., Amblas, D., Lastras, G., ... Calafat, A. M. (2012). Ploughing the deep sea floor. Nature, 489, 286-289. https://doi.org/10.1038/nature11410

Pusceddu, A., Bianchelli, S., Martín, J., Puig, P., Palanques, A., Masqué, P., \& Danovaro, R. (2014). Chronic and intensive bottom trawling impairs deep-sea biodiversity and ecosystem functioning. Proceedings 
of the National Academy of Sciences, 111, 8861-8866. https://doi. org/10.1073/pnas.1405454111

R Core Team. (2018). R: A language and environment for statistical computing. R Foundation for Statistical Computing. Retrieved from http:// www.R-project.org/

Reiss, H., Birchenough, S., Borja, A., Buhl-Mortensen, L., Craeymeersch, J., Dannheim, J., ... Degraer, S. (2015). Benthos distribution modelling and its relevance for marine ecosystem management. ICES Journal of Marine Science, 72, 297-315. https://doi.org/10.1093/icesjms/ fsu107

Reiss, H., Cunze, S., König, K., Neumann, H., \& Kröncke, I. (2011). Species distribution modelling of marine benthos a North Sea case study. Marine Ecology Progress Series, 442, 71-86. https://doi.org/10.3354/ meps09391

Ridgway, K. R., Dunn, J. R., \& Wilkin, J. L. (2002). Ocean interpolation by four-dimensional least squares - Application to the waters around Australia. Journal of Atmospheric and Ocean Technology, 19, 13571375. https://doi.org/10.1175/1520-0426(2002)019<1357:OIBFD W $>2.0 . \mathrm{CO} ; 2$

Sciberras, M., Hiddink, J. G., Jennings, S., Szostek, C. L., Hughes, K. M., Kneafsey, B., ... Kaiser, M. J. (2018). Response of benthic fauna to experimental bottom fishing: A global meta-analysis. Fish and Fisheries, 19, 698-715. https://doi.org/10.1111/faf.12283

Solan, M., Cardinale, B. J., Downing, A. L., Engelhardt, K. A. M., Ruesink, J. L., \& Srivastava, D. S. (2004). Extinction and Ecosystem Function in the Marine Benthos. Science, 306, 1177-1180. https://doi. org/10.1126/science.1103960

Stelzenmüller, V., Fock, H. O., Gimpel, A., Rambo, H., Diekmann, R., Probst, W. N., ... Kröncke, I. (2015). Quantitative environmental risk assessments in the context of marine spatial management: Current approaches and some perspectives. ICES Journal of Marine Science, 72, 1022-1042. https://doi.org/10.1093/icesjms/fsu206

Suuronen, P., Pitcher, C. R., McConnaughey, R. A., Kaiser, M., Hiddink, J. G., \& Hilborn, R. (2020). A path to a sustainable trawl fishery in
Southeast Asia. Reviews in Fisheries Science and Aquaculture, https:// doi.org/10.1080/23308249.2020.1767036

Thrush, S. F., \& Dayton, P. K. (2002). Disturbance to Marine Benthic Habitats by Trawling and Dredging: Implications for Marine Biodiversity. Annual Review of Ecology and Systematics, 33, 449-473. https://doi.org/10.1146/annurev.ecolsys.33.010802.150515

Trebilco, R., Halpern, B. S., Flemming, J. M., Field, C., Blanchard, W., \& Worm, B. (2011). Mapping species richness and human impact drivers to inform global pelagic conservation prioritisation. Biological Conservation, 144, 1758-1766. https://doi.org/10.1016/j. biocon.2011.02.024

Tulloch, V., Tulloch, A., Visconti, P., Halpern, B. S., Watson, J., Evan, M. C., ... Possingham, H. P. (2015). Why do we map threats? Linking threat mapping with actions to make better conservation decisions. Frontiers in Ecology and the Environment, 13, 91-99. https://doi. org/10.1890/140022

Zeileis, A. (2019). Package 'zoo'; S3 Infrastructure for Regular and Irregular Time Series. R version 1.8-6. Retrieved from https://cran.rproject.org/web/packages/zoo/zoo.pdf

\section{SUPPORTING INFORMATION}

Additional supporting information may be found online in the Supporting Information section.

How to cite this article: Mazor T, Pitcher CR, Rochester W, et al. Trawl fishing impacts on the status of seabed fauna in diverse regions of the globe. Fish Fish. 2020;00:1-15. https:// doi.org/10.1111/faf.12506 